\title{
Indomethacin treatment in small versus large premature infants with ductus arteriosus Comparison of plasma indomethacin concentration and clinical response
}

\author{
T F YEH, J LUKEN, D RAVAL, A THALJI, I CARR, R S PILDES \\ From the Division of Neonatology and Pediatric Cardiology, Cook County Children's Hospital and the University of \\ Illinois, Abraham Lincoln School of Medicine, and The Chicago Medical School, Chicago, Illinois, USA
}

SUMMARY An analysis of clinical response and plasma indomethacin concentration was performed on 10 small $(\leqslant 1000 \mathrm{~g}$ ) and 12 large $(>1000 \mathrm{~g}$ ) premature infants who had symptomatic ductus arteriosus and required intravenous indomethacin therapy $(0.3 \mathrm{mg} / \mathrm{kg}$ per day). The postnatal age, daily fluid intake, and cardiopulmonary status of the two groups at time of study were comparable.

The small premature infants had a significantly lower peak plasma indomethacin concentration and lower concentration in the first four hours after infusion, and lower plasma concentration $x$ time integral than that of the larger premature infants. There was a significant difference between the groups in proportion of response $(2 / 10$ vs $9 / 12)$ after one dose of indomethacin; this difference was not seen after two to three doses. The results of the study suggest that small premature infants do respond to indomethacin treatment, but compared to the larger infants may require repeated doses.

Poor or transient response to indomethacin in the closure of ductus arteriosus in premature infants of very low birthweight has been reported by some investigators ${ }^{2}$ but not by others. ${ }^{3-5}$ Various hypotheses have been suggested for these contradictory observations. One reason for the lack of response may be related to the day of postnatal age when indomethacin was administere ${ }^{1-3}$ because the closure of ductus arteriosus by indomethacin has been shown to be age dependent. ${ }^{6}$ The other reason for the inadequate response in small premature infants had been postulated to be because of inadequate development of the smooth muscle in the ductus wall.127 Recently, Brash et al. ${ }^{8}$ showed a relation between plasma indomethacin concentration and ductus constriction and suggested that some failure of indomethacin treatment may be related to a low plasma concentration. The purpose of the present study was to see if there were any differences in clinical response and plasma indomethacin concentration between the small and large premature infants.

Accepted for publication 10 February 1983

\section{Subjects and methods}

Serial assays for plasma indomethacin were performed in 22 premature infants who were enrolled in a double-blind study and received indomethacin because of the presence of a significant ductus arteriosus. ${ }^{9}$ The diagnosis of ductus arteriosus was made if the pulses were bounding and if there was the characteristic systolic murmur or murmur continued into diastole at the left upper sternal border. The criteria for inclusion in the study were: firstly evidence of a significant degree of clinical cardiovascular dysfunction' or an echocardiographic left atrial/aortic root dimension (LA/Ao) $\geqslant 1.3$ and secondly the absence of certain non-cardiopulmonary complicating factors. These factors included: (1) total serum bilirubin $171 \mu \mathrm{mol} / /(>10 \mathrm{mg} / 100 \mathrm{ml})$, (2) BUN 7.14 $\mathrm{mmol} / /$ (>20 mg/100 ml), (3) shock, (4) intracranial haemorrhage, (5) necrotising enterocolitis, and (6) haemorrhagic disease. After establishment of an intravenous line, each infant received $0.3 \mathrm{mg} / \mathrm{kg}$ birthweight of indomethacin sodium. There was no difficulty in infusing the drug completely in $15 \mathrm{sec}-$ onds in each case. Infants were examined daily and if 
a murmur was still present, another dose was administered up to a maximum of three doses. Therefore, all infants received at least one dose, but a smaller number received two doses and yet a smaller number, three doses. Doses were repeated at intervals of about 24 hours. All infants received $65 \mathrm{ml} / \mathrm{kg}$ per day on the first postnatal day; this was increased to approximately $150 \mathrm{ml} / \mathrm{kg}$ per day by 1 week of age. On the day before the study, and throughout the study period, the fluid intake was kept constant, with 120 $\mathrm{ml} / \mathrm{kg}$ per day or $150 \mathrm{ml} / \mathrm{kg}$ per day if the infant was on phototherapy. The plasma indomethacin concentration was measured during the first 24 hours after the first dose of indomethacin. Blood samples were obtained at a half, two, four, 12, and 24 hours after infusion of indomethacin. Assay of indomethacin was performed by the electron capture gas chromatographic method. ${ }^{11}$ The plasma concentration $\times$ time integral or the "area" under the plasma concentration time curve was calculated from time zero to 24 hours after drug infusion using a planimeter (Compensating Polar Planimeter, Keufell and Esser, Co., Morristown, New Jersey). Using clinical and echocardiographic assessments, a designation of "successful response" or "failure to respond" was assigned on the basis of information available 24 hours after drug administration. A successful response was defined by the disappearance of the murmur of ductus arteriosus and an improvement in the echocardiogram. All others were designated as failures.

The infants were divided into two groups. Group 1 consisted of 10 infants whose birthweights were less than or equal to $1000 \mathrm{~g}$; group 2 consisted of 12 infants whose birthweights were greater than $1000 \mathrm{~g}$. We evaluated statistical differences between the groups using the independent Student's $t$ test or $\chi^{2}$ analysis when appropriate.

\section{Results}

As would be expected, not only the mean birthweights but also the gestational ages were significantly $(\mathrm{p}<0.01)$ lower in group 1 infants $(837.8 \mathrm{~g}$, range 709 to $1000 \mathrm{~g} ; 29.5$ weeks, range 26 to 32 weeks) as compared with group 2 infants $(1391.8 \mathrm{~g}$, range 1162 to $1621 \mathrm{~g}$; 32.1 weeks, range 31 to 35 weeks).

The clinical characteristics and cardiopulmonary status of the infants at the time of study are shown in Table 1. There was no significant difference between the groups in postnatal age, cardiopulmonary status, and daily fluid intake, indicating that the two groups were comparable other than for birthweight and gestational ages.

Comparisons of the plasma indomethacin concentration between the two groups of infants are shown in Table 2. Infants in group 1 had significantly lower
Table 1 Clinical characteristics and cardiopulmonary status at time of study

\begin{tabular}{|c|c|c|c|}
\hline & $\begin{array}{l}\text { Group } 1 \\
(\leqslant 1000 \mathrm{~g})\end{array}$ & $\begin{array}{l}\text { Group } 2 \\
\left(>1000_{g}\right)\end{array}$ & $p$ \\
\hline $\begin{array}{l}\text { Total No. } \\
\text { Postnatal age (days) } \\
\text { Fluid intake (milkg per day) } \\
\text { Cardiopulmonary status } \\
\text { No. on assisted ventilation } \\
\mathrm{FIO}_{2} \\
\mathrm{Po}_{2} \text { (mmHg) } \\
\mathrm{PCO}_{2} \text { (mmHg) } \\
\text { PH } \\
\text { LA } \\
\text { LVED } \\
\text { CVD score } \\
\text { CVg } / \mathrm{kg})\end{array}$ & $\begin{array}{l}10 \\
10.1 \pm 4.2 \star \\
138.8 \pm 13.5 \\
8 \\
0.34 \pm 0.09 \\
54.7 \pm 7.5 \\
43.7 \pm 7.8 \\
7.33 \pm 0.06 \\
1.64 \pm 0.33 \\
1.34 \pm 0.33 \\
6.3 \pm 0.9\end{array}$ & $\begin{array}{c}12 \\
9.7 \pm 3.0 \\
136.2 \pm 10.5 \\
9 \\
9 \\
0.30 \pm 0.06 \\
62.8 \pm 6.9 \\
44.2 \pm 7.2 \\
7.34 \pm 0.06 \\
1.55 \pm 0.30 \\
1.26 \pm 0.30 \\
6.0 \pm 1 \cdot 2\end{array}$ & $\begin{array}{l}\text { NS } \\
\text { NS } \\
\text { NS } \\
\text { NS } \\
\text { NS } \\
\text { NS } \\
\text { NS }\end{array}$ \\
\hline
\end{tabular}

$\star$ Mean \pm SD.

$\mathrm{FO}_{2}$, fraction of inspired oxygen; Poz, partial pressure of oxygen; $\mathrm{PCO}_{2}$, pertial presaure of $\mathrm{CO}_{2} ; \mathrm{LN} \mathrm{N}_{\mathrm{O}}$, left atrial/eortic root dimeneion; LVEDD, left ventricle end-distolic dimension; CVD, candiovecular dyefunction.

Table 2 Comparison of senim indomethacin concentration between infants with birthweights $\leqslant 1000 \mathrm{~g}$ and those with $>1000_{g}$

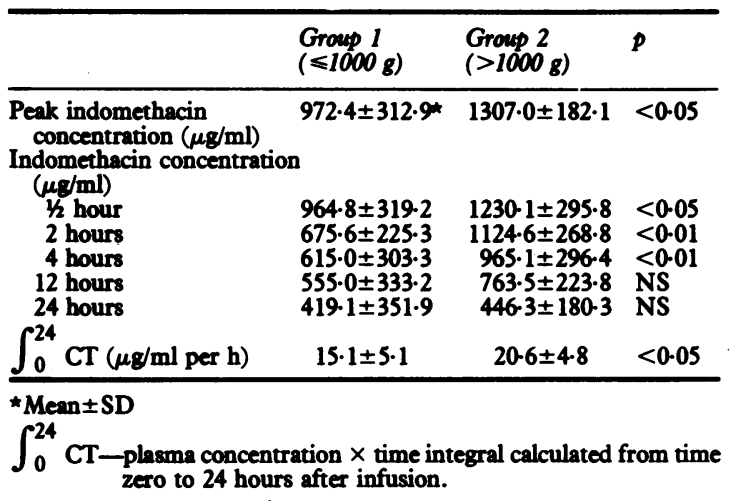

peak indomethacin concentration and lower indomethacin concentration at a half, two, and four hours after infusion, as compared with those of group 2 infants. Similarly, group 1 infants had significantly smaller plasma concentration $\times$ time integral calculated from time zero to 24 hours after infusion, as compared with that of group 2 infants.

Table 3 shows the number of infants who responded and did not respond to indomethacin therapy. Two infants in group 1 and nine in group 2 responded to one dose of indomethacin with closure of the ductus arteriosus. This difference, in proportion of response between the groups, was statistically significant $(p<0.05)$. After two to three doses of indomethacin, however, the proportion of response between the two groups was comparable. Group 1 infants received an average of $2.0 \pm 0.6$ doses (mean $\pm S D$ ) whereas group 2 infants received $1 \cdot 2 \pm 0.4$ doses $(p<0.01)$. 
Table 3 Number of infants who responded and did not respond to indomethacin: successful response defined by disappearance of murmur of ductus arteriosus and improvement of cardiopulmonary status

\begin{tabular}{llll}
\hline & $\begin{array}{l}\text { Group } 1 \\
(\leqslant 1000 \mathrm{~g}) \\
(10)\end{array}$ & $\begin{array}{l}\text { Groupp 2 } \\
(>1000 \mathrm{~g}) \\
(12)\end{array}$ & $p$ \\
\hline No. of successful responses: & $2 / 10$ & $9 / 12$ & $<0.05$ \\
After one dose & $2 / 8$ & NS \\
After two to three doses & $6 / 8$ & $3 / 3$ & NS \\
No. of failing responses & $2 / 10$ & $0 / 12$ & \\
\hline
\end{tabular}

\section{Discussion}

Indomethacin has been shown to be effective in the closure of the ductus arteriosus. ${ }^{91213}$ Emphasis has recently been focused on small premature infants with respiratory distress syndrome, not only because they have a high incidence of ductus arteriosus, ${ }^{14}$ but also because they have a high risk of developing bronchopulmonary dysplasia. Unfortunately, the ductus response to indomethacin in small premature infants has not always been successful; some infants did not respond, ${ }^{2}$ whereas others responded only transiently. ${ }^{1}$ On the other hand, such observations were not reported by other studies. ${ }^{581213}$ These inconsistent findings may arise from the differences between the studies in postnatal age of the infants, route, and doses used in drug administration, and in the definition of successful response. It is also possible that the ductal muscle in small premature infants is, indeed, inadequate, which can be attributed to the failure of ductal closure. The present study indicates that small premature infants do respond to indomethacin, but may require more doses than large premature infants if indomethacin is given at 24 hour intervals. This characteristic response in small premature infants may be related, at least in part, to their lower plasma concentration of indomethacin.

Since we do not have complete pharmacokinetic data on all infants, the lower plasma indomethacin concentration in small premature infants can only be speculated upon. It is known that small premature infants have large extracellular fluid space ${ }^{15}$ which may account for the large volume of distribution. Variation in serum protein concentration among the infants may also contribute to the variation of volume distribution since indomethacin is highly bound to serum protein. ${ }^{16}$ Small premature infants with lower serum protein concentration will enable more to diffuse out of the vascular compartment to other body fluid and tissue, lowering plasma concentration.

Brash et al. ${ }^{8}$ showed a positive relation between the ductus response and the plasma concentration of indomethacin at 24 hours after infusion. The same authors reported that $\mathbf{3 2}$ of $\mathbf{3 8}$ successful responses were associated with plasma levels above $250 \mu \mathrm{g} / \mathrm{ml}$ at 24 hours after infusion. Our study was not conducted to define the therapeutic level and our data do not clarify the question of target concentration or minimal exposure time above which the ductus closure will occur. Seven infants in our study, however (four in group 1 and three in group 2, postnatal age ranging from 5 to 10 days), whose indomethacin concentrations at 24 hours were greater than $250 \mu \mathrm{g} / \mathrm{ml}$, did not show evidence of response and required additional doses before the ductus closed. On the other hand, one infant $(1318 \mathrm{~g})$ whose indomethacin concentration at 24 hours was $<250 \mu \mathrm{g} / \mathrm{ml}$ showed evidence of ductal closure. Given the relatively small numbers, our findings and those of Brash et al. ${ }^{8}$ are not inconsistent and do not contradict the idea that ductal closure is related to plasma indomethacin concentration. It is likely that an indomethacin concentration dependent response would probably be represented by a continuum for each individual, with variation between individuals that seems to widen as more experience accumulated. It would be unwise to assume that infants with plasma indomethacin concentration $>250 \mu \mathrm{g} / \mathrm{ml}$ will have a good response; some obviously will not. Some of these small premature infants may require higher concentrations of indomethacin or require longer duration of exposure time to the drug than large infants. Further study is needed to define the therapeutic level of indomethacin in small premature infants.

Recently, Mahony et al. ${ }^{5}$ performed a double-blind controlled study of prophylactic indomethacin therapy in premature infants with subclinical ductus arteriosus. The authors reported a positive initial response in all 10 infants $\leqslant 1000 \mathrm{~g}$ based on clinical judgment. It is difficult to interpret the differences between their study and ours. All infants in Mahony's study did not have major left to right shunts, nor did they have echocardiographic changes in left atrium/ aorta ratio at the time of the study, while in our study, all infants had a ratio of $\geqslant 1.3$ and had cardiovascular distress. ${ }^{9}$ Mahony evaluated the initial response during the first 24 hours after the third dose of indomethacin, based on clinical judgment, while in our study the response was judged by clinical and echocardiographic criteria and was evaluated after each dose of indomethacin. Furthermore, their infants were younger ( 2.9 days) than ours. It is possible that small premature infants with substantial left to right shunts may not respond to indomethacin treatment as effectively as those with a subclinical ductus arteriosus occurring at an earlier postnatal age.

There may have been other factors responsible for the poor response to indomethacin, for example the inadequate muscular tissue in the ductal wall, as suggested by Danilowicz et al. ${ }^{7}$ or a primary histological 
anomaly of the ductus wall with unfragmented subendothelial elastic laminae as suggested by Gittenberger-de Groot. ${ }^{17}$ We did not evaluate those hypotheses but our results suggest that the inadequate response in our small premature infants may be related, at least in part, to the low plasma indomethacin concentration and low plasma indomethacin concentration time $\times$ integral.

\section{References}

1 Cooke RWI, Pickering D. Poor response to oral indomethacin therapy for persistent ductus arteriosus in very low birth weight infants. Br Heart f 1979; 41: 3013.

2 Ivey $\mathrm{HH}$, Kattwinkel J, Park TS, Krovetz LJ. Failure of indomethacin to close persistent ductus arteriosus in infants weighing under 1000 grams. Br Heart $\mathcal{f} 1979$; 41: 304-7.

3 Halliday HL, Hirata T, Brady JP. Indomethacin therapy for large patent ductus arteriosus in the very low birth weight infant: results and complications. Pediatrics 1979; 64: 153-9.

4 Merritt TA, Harris JP, Roghmann K, et al. Early closure of the patent ductus arteriosus in very low-birth-weight infants: a controlled trial. F Pediatr 1981; 99: 281-6.

5 Mahony L, Carnero V, Brett C, Heymann MA, Clyman RI. Prophylactic indomethacin therapy for patent ductus arteriosus in very-low-birth weight infants. $N$ Engl $\mathcal{F}$ Med 1982; 306: 506-10.

6 McCarthy JS, Zies LG, Gelband H. Age-dependent closure of the patent ductus arteriosus by indomethacin. Pediatrics 1978; 62: 706-12.

7 Danilowicz D, Rudolph AM, Hoffman JIE. Delayed closure of the ductus arteriosus in premature infants. Pediatrics 1966; 37: 74-8.

8 Brash AR, Hickey DE, Graham TP, Stahlman MT, Oates JA, Cotton RB. Pharmacokinetics of indomethacin in the neonate-relation of plasma indomethacin levels to response of the ductus arteriosus. $N$ Engl F Med 1981; 305: 67-72.
9 Yeh TF, Luken JA, Thalji A, Raval D, Carr I, Pildes RS. Intravenous indomethacin therapy in premature infants with persistent ductus arteriosus - a double-blind controlled study. F Pediatr 1981; 98: 137-45.

10 Yeh TF, Raval D, Luken J, Thalji A, Lilien LD, Pildes RS. Clinical evaluation of premature infants with patent ductus arteriosus: a scoring system with echocardiogram, acid-base and blood gas correlations. Crit Care Med 1981; 9: 655-7.

11 Helleberg L. Determination of indomethacin in serum and urine by electron-capture gas-liquid chromatography. F Chromatogr 1976; 117: 167-73.

12 Friedman WF, Hirschklau MJ, Printz MP, Pitlick PT, Kirkpatrick SE. Pharmacologic closure of patent ductus arteriosus in the premature infant. $N$ Engl $f$ Med 1976; 295: 526-9.

13 Heymann MA, Rudolph AM, Silverman NH. Closure of the ductus arteriosus in premature infants by inhibition of prostaglandin synthesis. $N$ Engl F Med 1976; 295: 530-33.

14 Siassi B, Blanco C, Cabal LA, Coran AG. Incidence and clinical features of patent ductus arteriosus in low birth weight infants: a prospective analysis of 150 consecutively born infants. Pediatrics 1976; 57: 347-51.

15 Friis-Hansen B. Body composition during growth. In vivo measurements and biochemical data correlated to differential anatomical growth. Pediatrics 1971; 47: 264-74.

16 Mason RW, McQueen EG. Protein binding of indomethacin; binding of indomethacin to human plasma albumin and its displacement from binding by ibuprofen, phenylbutazone and salicylate in vitro. Pharmacology 1974; 12: 12-9.

17 Gittenberger-de Groot AC. Persistent ductus arteriosus: most probably a primary congenital malformation. $\mathrm{Br}$ Heart $f$ 1977; 39: 610-18.

Requests for reprints to Dr T F Yeh, Division of Neonatology, Cook County Children's Hospital, 700 South Wood Street, Chicago, Illinois 60612, USA. 